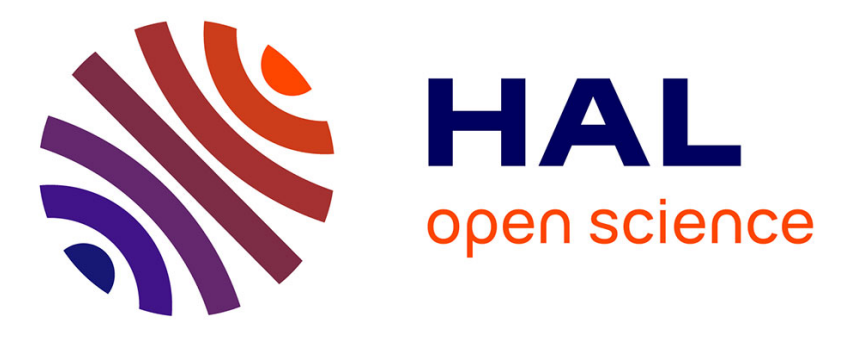

\title{
Degradation of chlordecone and beta-hexachlorocyclohexane by photolysis, (photo-)fenton oxidation and ozonation
}

Germán Cruz González, Carine Julcour-Lebigue, Hélène Chaumat, Valérie Bourdon, Felipe Ramon-Portugal, Sarra Gaspard, Ulises J. Jáuregui-Haza, Henri Delmas

\section{To cite this version:}

Germán Cruz González, Carine Julcour-Lebigue, Hélène Chaumat, Valérie Bourdon, Felipe RamonPortugal, et al.. Degradation of chlordecone and beta-hexachlorocyclohexane by photolysis, (photo)fenton oxidation and ozonation. Journal of Environmental Science and Health, Part B, 2018, 53 (2), pp.121-125. 10.1080/03601234.2017.1388682 . hal-01950009

\section{HAL Id: hal-01950009 \\ https://hal.science/hal-01950009}

Submitted on 10 Dec 2018

HAL is a multi-disciplinary open access archive for the deposit and dissemination of scientific research documents, whether they are published or not. The documents may come from teaching and research institutions in France or abroad, or from public or private research centers.
L'archive ouverte pluridisciplinaire HAL, est destinée au dépôt et à la diffusion de documents scientifiques de niveau recherche, publiés ou non, émanant des établissements d'enseignement et de recherche français ou étrangers, des laboratoires publics ou privés. 


\section{OATAO \\ Open Archive Toulouse Archive Ouverte}

\section{Open Archive Toulouse Archive Ouverte}

OATAO is an open access repository that collects the work of Toulouse researchers and makes it freely available over the web where possible

This is an author's version published in: http://oatao.univ-toulouse.fr/21147

Official URL: https://doi.org/10.1080/03601234.2017.1388682

\section{To cite this version:}

Cruz González, Germán $\rightleftharpoons$ and Julcour-Lebigue, Carine $\leftrightarrows$ and Chaumat, Hélène ${ }^{-\supset}$ and Bourdon, Valérie and Ramon-Portugal, Felipe and Gaspard, Sarra and Jáuregui-Haza, Ulises J. and Delmas, Henri' Degradation of chlordecone and beta-hexachlorocyclohexane by photolysis, (photo-)fenton oxidation and ozonation. (2018) Journal of Environmental Science and Health, Part B, 53 (2). 121-125. ISSN 0360-1234

Any correspondence concerning this service should be sent to the repository administrator: tech-oatao@listes-diff.inp-toulouse.fr 


\title{
Degradation of chlordecone and beta-hexachlorocyclohexane by photolysis, (photo-)fenton oxidation and ozonation
}

\author{
Germán Cruz-González ${ }^{\mathrm{a}, \mathrm{b}}$, Carine Julcour $\mathbb{D}^{\mathrm{a}}$, Hélène Chaumat $\mathbb{D}^{\mathrm{a}}$, Valérie Bourdon ${ }^{\mathrm{c}}$, Felipe Ramon-Portugal $\mathbb{D}^{\mathrm{d}}$, \\ Sarra Gaspard ${ }^{\mathrm{e}}$, Ulises J. Jáuregui-Haza $\mathbb{1}^{\mathrm{b}}$, and Henri Delmas ${ }^{\mathrm{a}}$
}

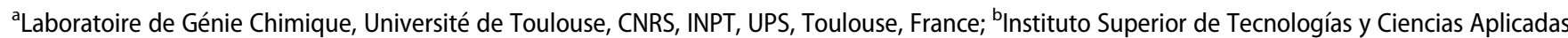
(InSTEC)- Universidad de La Habana, Avenida Salvador Allende No 1110 entre Infanta y Avenida Rancho Boyeros, Quinta de los Molinos, A.P. 6163, La Habana, Cuba; 'Service Commun de Spectrométrie de Masse, Université Paul Sabatier, Porte 157, Bâtiment 2R1, 118, route de Narbonne, Toulouse Cedex 09, France; 'UMR CNRS/UPS/ENFA 5174 "Evolution et Diversité Biologique", École National de Formation Agronomique, 2, Route de Narbonne, BP 22687, Auzeville Tolosane, Castanet Cedex, France; 'Laboratoire COVACHIM M2E, EA 3592, Université des Antilles et de la Guyane, BP 250, Pointe à Pitre Cedex, Guadeloupe
\end{abstract}

\begin{abstract}
Intensive use of chlorinated pesticides from the 1960s to the 1990s has resulted in a diffuse contamination of soils and surface waters in the banana-producing areas of the French West Indies. The purpose of this research was, for the first time, to examine the degradation of two of these persistent pollutants chlordecone (CLD) and beta-hexachlorocyclohexane $(\beta-\mathrm{HCH})$ in $1 \mathrm{mg} \mathrm{L}^{-1}$ synthetic aqueous solutions by means of photolysis, (photo-) Fenton oxidation and ozonation processes. Fenton oxidation is not efficient for CLD and yields less than 15\% reduction of $\beta$ - $\mathrm{HCH}$ concentration in $5 \mathrm{~h}$. Conversely, both molecules can be quantitatively converted under UV-Vis irradiation reaching $100 \%$ of degradation in $5 \mathrm{~h}$, while combination with hydrogen peroxide and ferrous iron does not show any significant improvement except in high wavelength range $(>280 \mathrm{~nm}$ ). Ozonation exhibits comparable but lower degradation rates than UV processes. Preliminary identification of degradation products indicated that hydrochlordecone was formed during photo-Fenton oxidation of $C L D$, while for $\beta-\mathrm{HCH}$ the major product peak exhibited $\mathrm{C}_{3} \mathrm{H}_{3} \mathrm{Cl}_{2}$ as most abundant fragment.
\end{abstract}

\section{Introduction}

Banana and sugarcane have been the main agricultural products of the French Antilles (Guadeloupe and Martinique) since the 1960s. To prevent crop damages from the banana weevil, chlorinated pesticides, such as chlordecone $\left(\mathrm{CLD}, \mathrm{C}_{10} \mathrm{Cl}_{10} \mathrm{O}\right.$, CAS-number: 143-50-0), $\beta$-hexachlorocyclohexane $(\beta-\mathrm{HCH}$, $\mathrm{C}_{6} \mathrm{Cl}_{6} \mathrm{H}_{6}$, CAS-number: 319-85-7) and dieldrine were extensively used until the beginning of the 1990s, resulting in the contamination of both the soil and the surface waters. ${ }^{[1,2]}$ It was not until 2009, when they were listed as persistent organic pollutants under the Stockholm Convention, ${ }^{[3]}$ that the production and agricultural use of the first two pesticides was prohibited worldwide. ${ }^{[3]}$

Chlordecone has a low solubility in water $\left(2.7 \mathrm{mg} \mathrm{L}^{-1}\right.$ at $25^{\circ} \mathrm{C}^{[4]}$ ) and its vapor tension is less than $3 \times 10^{-7} \mathrm{mmHg}$ at $25^{\circ} \mathrm{C}^{[1]}$ It has a strong affinity for lipids, accumulates in the food chain ${ }^{[5,6]}$ and is known for its endocrine-disrupting character $^{[7]}$ and carcinogenic potential. ${ }^{[8,10]}$ Used since 1972, it was banned in 1993 in the French West Indies. Nonetheless, pollution surveys conducted in 2001 by the French Department of Health still revealed the presence of chlordecone in soils, rivers, springs and drinking water of Antilles, as well as in food crop products such as root vegetables. ${ }^{[1]}$ More recent studies in the same area measured concentrations of chlordecone between 0.1 and $37.4 \mathrm{mg} \mathrm{kg}^{-1}$ in soils. ${ }^{[4]}$

$\mathrm{HCH}$ was spread on the form of technical $\mathrm{HCH}$ consisting of eight isomers whose water solubility varies between 5 (for $\beta$-HCH) and $20 \mathrm{mg} \mathrm{L}^{-1}$ and vapor tension between $3.54 \times$ $10^{-5}$ (for $\beta-\mathrm{HCH}$ ) and $0.003 \mathrm{~Pa}$ at $20^{\circ} \mathrm{C}^{[11]}$ Mainly four of them are found in technical grade products, $\beta$ - $\mathrm{HCH}$ (accounting for 5 to $12 \%$ of technical $\mathrm{HCH}$ ) being considered as the most recalcitrant. ${ }^{[12]}$ Available toxicity data for this isomer are limited, especially concerning human health, because exposure mainly occurs with $\mathrm{HCH}$ mixture or pesticidally active lindane $(\gamma-\mathrm{HCH})$. Neurotoxic effects were reported from animal studies and it is classified as possibly human carcinogenic. ${ }^{[11]}$ Technical HCH was mainly used in the 1960s and 1970s in the Antilles (before CLD was introduced), with amount as high as $350 \mathrm{~kg} \mathrm{ha}^{-1}$ year $^{-1}$. $^{12]}$ Such extensive application should explain why $\beta-\mathrm{HCH}$ is still the pesticide the most frequently detected in surface waters of Martinique after CLD. ${ }^{[13]}$

Thus, there is growing political and social pressure to find remediation solutions for CLD and $\beta$-HCH problem in the French West Indies. Physical treatments applied for the removal of pesticides from contaminated wastewater, such as coagulation, flocculation, 
membrane separation or adsorption on activated carbon, only operate a transfer of the pollutants which still have to be destroyed. Biological solutions are under development, ${ }^{[14,15]}$ but they are limited by slow degradation kinetics or use of anoxic conditions. On the other hand, advanced oxidation processes like (photo-)Fenton oxidation or ozonation have been applied for the degradation of several classes of pesticides and refractory compounds such as thiamethoxam, ${ }^{[16]}$ lindane, ${ }^{[17-20]}$ parathion and dichlorvos, ${ }^{[18]}$ endosulfan, ${ }^{[19]}$ linuron, ${ }^{[21]}$ bromoxynil and trifluralin, ${ }^{[22]}$ monuron, ${ }^{[23]}$ 2,4-dichlorofenoxyacetic acid. ${ }^{[24]}$ Except one patent for CLD, ${ }^{[25]}$ only very recent works investigated chemical processes for the remediation of $\mathrm{CLD}^{[26]}$ and $\beta-\mathrm{HCH}^{[27,29]}$ The purpose of this work is, for the first time, to examine the degradation of CLD and $\beta$-HCH in synthetic aqueous solutions by means of photolysis, (photo-)Fenton oxidation and ozonation.

\section{Materials and methods}

\section{Chemicals}

CLD and $\beta$-HCH were supplied by Sigma-Aldrich with a purity $\geq 99.0 \%$. $700 \mathrm{~mL}$ of pesticide solutions with an initial concentration of $1 \mathrm{mg} \mathrm{L}^{-1}$ (corresponding to $2.0 \mu \mathrm{mol} \mathrm{L}^{-1}$ for CLD and $3.4 \mu \mathrm{mol} \mathrm{L}{ }^{-1}$ for $\beta$-HCH) were treated by photo-mediated processes. For ozonation experiments only $250 \mathrm{~mL}$ were used. All the samples were prepared by diluting a stock solution ( $0.5 \mathrm{~g} \mathrm{~L}^{-1}$ of pesticide in acetone) into demineralized water. For Fenton and photo-Fenton experiments they were then acidified to $\mathrm{pH} 2.6$ using $10 \% \mathrm{H}_{2} \mathrm{SO}_{4}$ (95-97\%, Sigma Aldrich).

Hydrogen peroxide ( $\mathrm{Ph}$ Eur, 30\% w/w solution, SigmaAldrich) and $\mathrm{Fe}_{2} \mathrm{SO}_{4} .7 \mathrm{H}_{2} \mathrm{O}$ (99.5\%, Sigma-Aldrich) were applied as Fenton's reagents. Methanol (99\%, Scharlau Chemie) was used to quench homogeneous Fenton reaction by scavenging hydroxyl radicals. ${ }^{[30]}$

\section{Experimental setups}

Photolysis and (photo-)Fenton experiments were conducted in a $1 \mathrm{~L}$ stirred Pyrex reactor, equipped with a jacket to maintain the temperature of the solution at $30^{\circ} \mathrm{C}$. It included a medium-pressure mercury vapor lamp (MP Hg, 450 W Hanovia PC451.050 lamp, arc length $4.8 \mathrm{~cm}$ ) or a low-pressure mercury vapor lamp (LP Hg, $10 \mathrm{~W}$ Heraeus GPH212T5L/4 lamp) placed in either a jacketed quartz or borosilicate glass immersion well. The solution was agitated by a magnetic stirrer rotated at $350 \mathrm{rpm}$ and by gentle bubbling of air. It was checked from blank experiments that no stripping or adsorption of the CLD or $\beta$-HCH occurred during the reaction time $(5 \mathrm{~h}) .7 \mathrm{~mL}$ aliquots were sampled at selected time intervals, treated with methanol (using 1:1 w/w mixture of sample and $\mathrm{MeOH}$ ) and centrifuged when Fenton's reagent was present.

The stoichiometric amount of $\mathrm{H}_{2} \mathrm{O}_{2}$ required for the mineralization of the pesticides was calculated based on the following equations, for (1) CLD and (2) $\beta$-HCH:

$$
\begin{gathered}
\mathrm{C}_{10} \mathrm{Cl}_{10} \mathrm{O}+\mathbf{1 4} \mathrm{H}_{2} \mathrm{O}_{2}=10 \mathrm{CO}_{2}+9 \mathrm{H}_{2} \mathrm{O}+\mathbf{1 0 H C l} \\
\mathrm{C}_{6} \mathrm{Cl}_{6} \mathrm{H}_{6}+12 \mathrm{H}_{2} \mathrm{O}_{2}=6 \mathrm{CO}_{2}+12 \mathrm{H}_{2} \mathrm{O}+\mathbf{6 H C l}
\end{gathered}
$$

A $\mathrm{H}_{2} \mathrm{O}_{2}$ dosage equivalent to 20 times the stoichiometric amount and a molar ratio of $\mathrm{H}_{2} \mathrm{O}_{2}$ to $\mathrm{Fe}^{2+}$ equal to 2 were used for the Fenton experiments. It corresponded to the following concentrations of the Fenton's reagent: $0.6 \mathrm{mmol} \mathrm{L}{ }^{-1}$ of $\mathrm{H}_{2} \mathrm{O}_{2}$ and $0.3 \mathrm{mmol} \mathrm{L}^{-1}$ of $\mathrm{Fe}(\mathrm{II})$ for CLD; $0.8 \mathrm{mmol} \mathrm{L}{ }^{-1}$ of $\mathrm{H}_{2} \mathrm{O}_{2}$ and $0.4 \mathrm{mmol} \mathrm{L}^{-1}$ of $\mathrm{Fe}(\mathrm{II})$ for $\beta-\mathrm{HCH}$. The Fenton reaction was initiated by the addition of $\mathrm{H}_{2} \mathrm{O}_{2}$.

Ozonation was performed in a $0.5 \mathrm{~L}$ cylindrical glass reactor and the solution was agitated by bubbling of ozone. For all the experiments the initial $\mathrm{pH}$ of the solution was 5.3. Ozone was produced from pure oxygen by a WEDECO 4-HC Ozone Generator. The gas mixture containing $48 \mathrm{~g}$ $\mathrm{Nm}^{-3}$ of ozone was continuously bubbled into the solution through a porous distributor plate at a flow rate of $30 \mathrm{~L} \mathrm{~h}^{-1}$. Blank runs were also performed with nitrogen only, to check for the absence of any pollutant stripping or adsorption on reactor internals. Withdrawn samples were not treated before analyses.

\section{Analytical methods}

A LC-MS/MS with external standardization was used to follow the evolution of CLD and $\beta$ - $\mathrm{HCH}$ concentrations.

\section{LC-MS/MS analysis}

Analysis conditions: (Treated) reaction samples (50 and $80 \mu \mathrm{L}$ for CLD and $\beta$ - $\mathrm{HCH}$, respectively) were directly injected in an Agilent 1100 liquid chromatograph coupled to a triple quadrupole-linear ion trap mass spectrometer (Qtrap 2000, ABSciex). The separation column was a C18 Waters Xbridge $(100 \mathrm{~mm} \times$ $3.0 \mathrm{~mm}$ I.D. and $3.5 \mu \mathrm{m}$ particle size) thermostated at $50^{\circ} \mathrm{C}$. Mobile phases were (A) ultrapure water, with $10 \mathrm{mmol} \mathrm{L}^{-1}$ of ammonium formate and (B) HPLC grade acetonitrile in the case of CLD samples; (A) ultrapure water and (B) HPLC grade acetonitrile in the case of $\beta$ - $\mathrm{HCH}$ samples. They were delivered in $40 / 60 \mathrm{v} / \mathrm{v}$ isocratic mode of $\mathrm{A}$ and $\mathrm{B}$, at a total flow rate of $0.5 \mathrm{~mL} \mathrm{~min}^{-1}$. The mass spectrometer was used in MS/MS, negative APCI, multiple reaction monitoring (MRM) mode and the following mass transitions $(\mathrm{m} / \mathrm{z})$ were followed: 506.85-427 (CLD) and 321.8-195 ( $\beta$-HCH). Declustering potential (DP) and collision energy $(\mathrm{CE})$ were optimized to the following values: $\mathrm{DP}=-80$ and $\mathrm{CE}=-28$ for CLD, $\mathrm{DP}$ $=-40$ and $\mathrm{CE}=-18$ for $\beta-\mathrm{HCH}$. The data were recorded and treated with Analyst 1.6.2 software (AB Sciex).

Calibration method: An external standardization procedure was applied for LC-MS/MS analysis, using for each experiment a different calibration curve established in the $0.05-0.5 \mathrm{ppm}$ range. In the case of (photo-)Fenton oxidation, a specific procedure was followed for its construction, so as to minimize variations in response coefficient ascribed to the presence of dissolved iron and quenching agent: the 0.5 ppm standard was prepared by mixing the pollutant solution containing ferrous iron with methanol $(1: 1 \mathrm{w} / \mathrm{w})$, as for the oxidation samples. Then, a solution consisting in a 1:1 (w/w) mixture of acidic ferrous iron solution (same as previously, but without pollutant) and methanol was used to obtain the other standards by successive dilution of the first one, thereby keeping ferrous iron and $\mathrm{MeOH}$ concentrations unchanged. The standards were finally centrifuged as treated samples. Quantification limit was $0.05 \mathrm{ppm}$ for CLD and $\beta-\mathrm{HCH}$. 


\section{Results and discussion}

\section{Comparison of the different AOPs for CLD degradation}

Photolysis (using first a large UV-Vis spectrum), (photo-)Fenton oxidation and ozonation were investigated for the removal of CLD, and their results are shown in Fig. 1. Error bars indicate the deviation from the mean of triplicate experiments.

First, it should be noticed that although hydroxyl radicals generated by AOPs are reported to be highly reactive and nonselective, Fenton oxidation did not yield any significant conversion of the contaminant in the investigated condition. As the solution also contained a significant amount of acetone which was used to help the pesticide dissolution into water (cf. $\S 2.1$ ), a complementary experiment was carried out with a tenfold $\mathrm{H}_{2} \mathrm{O}_{2}$ dosage (while keeping the same $\mathrm{H}_{2} \mathrm{O}_{2} / \mathrm{Fe}$ ratio); however the degradation of CLD remained negligible. Such low reactivity might result from the high steric hindrance of the molecule. On the other hand, ozone was able to achieve $70 \%$ of pesticide removal within $2 \mathrm{~h}$. In this case, both molecular and radical mechanisms should be involved, the latter being favored by high $\mathrm{pH}$ values. ${ }^{[31]} \mathrm{An}$ inhibition of radical process could be then suspected.

CLD could be readily degraded by direct photolysis, to more than $95 \%$ in $3 \mathrm{~h}$. Addition of the Fenton's reagent resulted in no appreciable improvement of the removal rate, and thus hydroxyl radical mechanism that should be enhanced under UV-Vis irradiation (through $\mathrm{H}_{2} \mathrm{O}_{2}$ photolysis and ferrous iron regeneration) did not seem to play any noticeable role either.

To further investigate photo-assisted processes, the applied wavelength range was varied by using the MP Hg lamp with a glass immersion well and a LP Hg lamp (with quartz lamp holder). According to the supplier, the MP Hg lamp emitted $40-48 \%$ of its energy is in the ultraviolet portion of the spectrum and $40-43 \%$ in the visible range. The glass holder should cut most of the radiation below $280 \mathrm{~nm}$, about $50 \%$ of the emission at $310 \mathrm{~nm}$, and showed full transmittance above $355 \mathrm{~nm}$. On the other hand, the LP Hg lamp mainly exhibited a monochromatic emission at $254 \mathrm{~nm}$. Results are shown in Fig. 2 for both photolysis and photo-Fenton oxidation.

For both the processes, the removal yield of CLD ranged in the order: MP Hg lamp + quartz lamp holder > LP Hg lamp + quartz lamp holder $>$ MP Hg lamp + borosilicate lamp holder. As photolysis mechanism was shown as the dominant process, this could be explained by the absorbance spectrum of

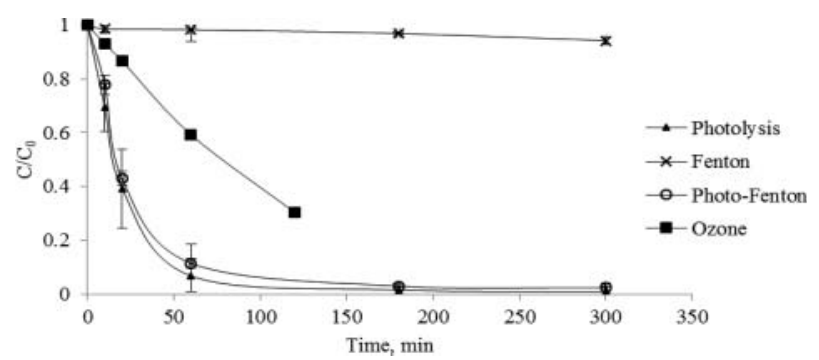

Figure 1. Degradation of CLD by photolysis, Fenton, photo-Fenton and ozonation processes. $[C L D]_{0}=2 \mu \mathrm{mol} \mathrm{L}^{-1}, T=30^{\circ} \mathrm{C} ; 450 \mathrm{~W} \mathrm{MP} \mathrm{Hg}$ lamp and quartz lamp holder for photo-assisted processes; $\left[\mathrm{H}_{2} \mathrm{O}_{2}\right]_{0}=0.6 \mathrm{mmol} \mathrm{L}^{-1},[\mathrm{Fe}(\mathrm{II})]_{0}=0.3 \mathrm{mmol}$ $\mathrm{L}^{-1}$ and $\mathrm{pH}_{0}=2.6$ for Fenton-based oxidation.

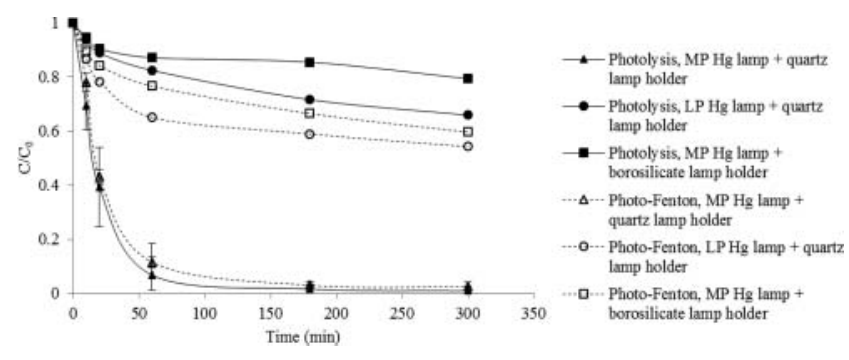

Figure 2. Effect of irradiation spectrum on the degradation of CLD by photoassisted processes. [CLD $]_{0}=2 \mu \mathrm{mol} . \mathrm{L}^{-1}, T=30^{\circ} \mathrm{C}$; photo-Fenton: $\left[\mathrm{H}_{2} \mathrm{O}_{2}\right]_{0}=$ $0.6 \mathrm{mmol} \mathrm{L}^{-1},[\mathrm{Fe}(\mathrm{II})]_{0}=0.3 \mathrm{mmol} \mathrm{L}^{-1}, \mathrm{pH}_{0}=2.6$.

the molecule which exhibited maxima at 210 and $320 \mathrm{~nm}$ and differences in lamp irradiation intensity in this wavelength range. Cutting (first) absorption maximum of CLD at $210 \mathrm{~nm}$ strongly reduced the molecule photodegradation. On the other hand, the higher rate observed at $\lambda=254 \mathrm{~nm}$ than at $\lambda>280 \mathrm{~nm}$ (while another absorption peak is observed at 320 $\mathrm{nm}$ ) might be due to the presence of acetone, which was reported to act as photo-sensitizer. ${ }^{[32]}$ Moreover, when the glass lamp holder dramatically hindered photolysis, effect of Fenton's reagent addition more clearly stood out, indicating that a radical-mediated mechanism in fact contributed, but to a much lower extent.

Kitchens ${ }^{[25]}$ investigated the removal of CLD by UV, UV/ $\mathrm{O}_{3}$, and $\mathrm{UV} / \mathrm{H}_{2}$ in basic aqueous solution and (alkalinized) methanol using a $30 \mathrm{~W}$ UV lamp irradiating at $254 \mathrm{~nm}$. In aqueous $\mathrm{NaOH}$ solution, $\mathrm{UV} / \mathrm{H}_{2}$ was found to be the most efficient treatment with $84 \%$ conversion of the molecule within $120 \mathrm{~min} v$ s. $39 \%$ and $21 \%$ for $\mathrm{UV}$ and $\mathrm{UV} / \mathrm{O}_{3}$, respectively. This latter result is much lower than that observed for ozonation in the present study, without irradiation and at slightly acidic $\mathrm{pH}$. This is in line with a weak contribution of hydroxyl radicals in the investigated $\mathrm{pH}$. With the MP Hg lamp, similar performance as the proposed $\mathrm{UV} / \mathrm{H}_{2}$ process could be achieved, but this process might be more expensive and dangerous than (photo-) Fenton oxidation.

\section{Comparison of the different AOPs for $\beta$-HCH degradation}

Figure 3 provides a comparison of the same AOPs as in Fig. 1, but for the case of $\beta-\mathrm{HCH}$. It also exhibits essentially the same features: almost insignificant oxidation rate by Fenton's reagent and thus a photo-Fenton process mainly driven by the direct photolysis of the molecule.

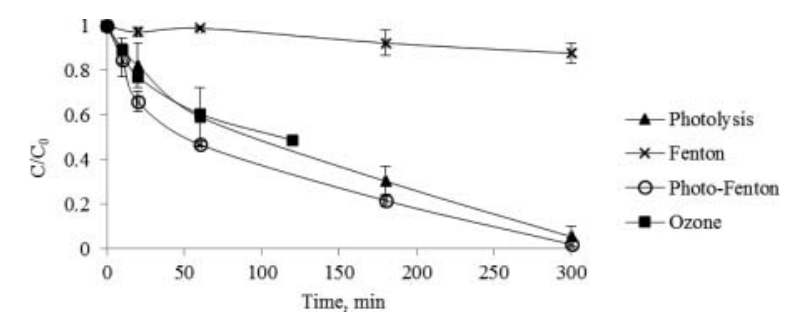

Figure 3. Degradation of $\beta$-HCH by photolysis, Fenton, UV/Fenton and ozonation processes. $[\beta-\mathrm{HCH}]_{0}=3.4 \mu \mathrm{mol} \mathrm{L}^{-1}, T=30^{\circ} \mathrm{C} ; 450 \mathrm{~W} \mathrm{MP} \mathrm{Hg}$ lamp and quartz lamp holder for photo-assisted processes; $\left[\mathrm{H}_{2} \mathrm{O}_{2}\right]_{0}=0.8 \mathrm{mmol} \mathrm{L}^{-1},[\mathrm{Fe}(\mathrm{II})]_{0}=$ $0.4 \mathrm{mmol} \mathrm{L}^{-1}$ and $\mathrm{pH}_{0}=2.6$ for Fenton-based oxidation. 


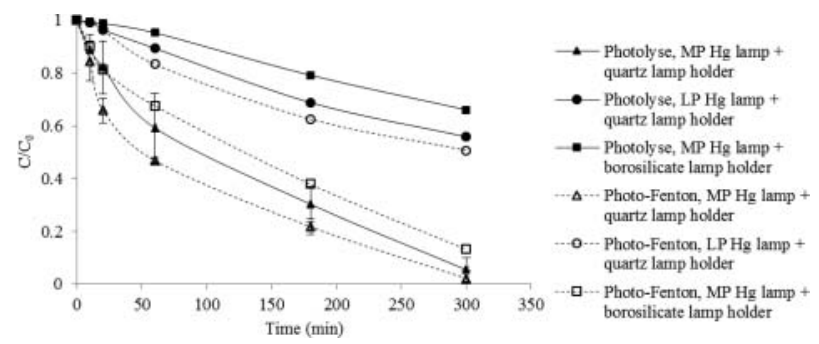

Figure 4. Effect of irradiation spectrum on the degradation of $\beta$ - $\mathrm{HCH}$ by photoassisted processes. $[\beta-\mathrm{HCH}]_{0}=3.4 \mu \mathrm{mol} \mathrm{L}^{-1}, T=30^{\circ} \mathrm{C}$; photo-Fenton: $\left[\mathrm{H}_{2} \mathrm{O}_{2}\right]_{0}=$ $0.8 \mathrm{mmol} \mathrm{L}^{-1},[\mathrm{Fe}(\mathrm{II})]_{0}=0.4 \mathrm{mmol} \mathrm{L}^{-1}, \mathrm{pH}_{0}=2.6$.

Effect of lamp irradiation was also investigated (Fig. 4) and the most striking result was a still high elimination of $\beta-\mathrm{HCH}$ by photo-Fenton oxidation under UVB-Vis.

To our knowledge, only scarce information related to the advanced oxidation of this pesticide has been reported. The work of Usman et al. (2014) performed on contaminated soils indicated a much lower degradation of $\beta$ - $\mathrm{HCH}$ by Fenton's reagent with respect to $\gamma-\mathrm{HCH}(25 \% v s .90 \%)$. On the other hand, Ormad et al. ${ }^{[27]}$ studied the degradation of a group of pesticides including $\beta$ - $\mathrm{HCH}$ in very diluted conditions $(0.5 \mu \mathrm{g}$ $\mathrm{L}^{-1}$ ) by ozonation, $\mathrm{O}_{3} / \mathrm{H}_{2} \mathrm{O}_{2}, \mathrm{O}_{3} / \mathrm{TiO}_{2}$ and $\mathrm{O}_{3} / \mathrm{H}_{2} \mathrm{O}_{2} / \mathrm{TiO}_{2}$ processes. The degradation of $\beta$ - $\mathrm{HCH}$ was only possible when the process $\mathrm{O}_{3} / \mathrm{H}_{2} \mathrm{O} / \mathrm{TiO}_{2}$ was used with an ozone flow of $3 \mathrm{mgL}^{-1}$, for an $\mathrm{O}_{3}$ /pollutant ratio close to one. In these conditions a degradation of the $\beta-\mathrm{HCH}$ of $10 \%$ was achieved.

Preliminary identification of degradation products indicated that hydrochlordecone was formed during photo-Fenton oxidation of CLD, while for $\beta-\mathrm{HCH}$ the major product peak exhibited $\mathrm{C}_{3} \mathrm{H}_{3} \mathrm{Cl}_{2}$ as most abundant fragment.

In order to compare the different processes studied for the degradation of both pesticides, their kinetics constants were calculated following a pseudo-first order model (Table 1).

As we can observe for the CLD the best process was the photolysis, followed by the photo-Fenton and the ozone, all with the same order of magnitude, and the Fenton process was the less effective with 2 orders of magnitude below. In the case of $\beta-\mathrm{HCH}$, the behavior was similar to CLD but the photolysis and photo-Fenton processes have the same rate constants.

On the other hand, $\beta$ - $\mathrm{HCH}$ was found less sensitive to UV irradiation, its first-order photolysis rate constant being $2.10^{-4} \mathrm{~s}^{-1}$, much smaller than that of CLD $\left(8.10^{-4} \mathrm{~s}^{-1}\right)$. $\beta$-HCH also showed a slightly lower reactivity towards ozone, with about $50 \%$ conversion after $2 \mathrm{~h}$ (against $70 \%$ for CLD).

Finally, with the aim of comparing the efficiency of the photolytic processes a study of the electrical energy per order

Table 1. Kinetics constants of the different process studied for the pesticides degradation.

\begin{tabular}{lccc}
\hline Process & Pesticide & $k\left(\mathrm{~s}^{-1}\right)$ & $R^{2}$ \\
\hline Photolysis & $\mathrm{CLD}$ & $8.10^{-4}$ & 0.99 \\
Fenton & & $3.10^{-6}$ & 0.94 \\
Photo-Fenton & $6.10^{-4}$ & 0.99 \\
Ozone & & $2.10^{-4}$ & 0.99 \\
Photolysis & $\beta$-HCH & $2.10^{-4}$ & 0.99 \\
Fenton & & $7.10^{-6}$ & 0.97 \\
Photo-Fenton & & $2.10^{-4}$ & 0.99 \\
Ozone & & $1.10^{-4}$ & 0.96 \\
\hline
\end{tabular}

Table 2. Electrical energy per order for the photolytic processes.

\begin{tabular}{lcccccc}
\hline Process & $t(\mathrm{~h})$ & $\begin{array}{c}\mathrm{C}_{0} \\
\left(\mathrm{mg} \mathrm{L}^{-1}\right)\end{array}$ & $\begin{array}{c}C \\
\left(\mathrm{mg} \mathrm{L}^{-1}\right)\end{array}$ & $\begin{array}{c}P \\
(\mathrm{~kW})\end{array}$ & $\begin{array}{c}V \\
(\mathrm{~L})\end{array}$ & $\begin{array}{c}\mathrm{EE} / \mathrm{O} \\
\left(\mathrm{kWh} \mathrm{L}^{-1}\right)\end{array}$ \\
\hline Photolysis $(\mathrm{CLD})$ & 5 & 1 & 0.01 & 0.45 & 0.7 & 1.60 \\
Photolysis $(\beta$-HCH) & 5 & 1 & 0.05 & 0.45 & 0.7 & 2.47 \\
Photo-Fenton $(\mathrm{CLD})$ & 5 & 1 & 0.02 & 0.45 & 0.7 & 1.89 \\
Photo-Fenton $(\beta$-HCH) & 5 & 1 & 0.02 & 0.45 & 0.7 & 1.89 \\
\hline
\end{tabular}

$(\mathrm{EE} / \mathrm{O})$ was carried out. The $\mathrm{EE} / \mathrm{O}$ was calculated by the Eq. (3), proposed by Bolton and Cater. ${ }^{[33]}$

$$
\frac{E E}{O}=\frac{P \times t}{V \times \log \frac{C_{0}}{C}}
$$

As we can see in Table 2, the most efficient process for CLD degradation was the photolysis, with the lowest $\mathrm{EE} / \mathrm{O}$ of all the studied process. However, for the degradation of $\beta$ - $\mathrm{HCH}$ the lowest EE/O was obtained for the photo-Fenton process. This behavior could be explained by the lowest sensibility to the UV radiation observed in this study by the $\beta$-HCH.

\section{Conclusions}

In the investigated conditions, both chlordecone and beta-hexachlorocyclohexane exhibited a much lower reactivity towards Fenton's reagent $(<10 \%$ conversion in $2 \mathrm{~h})$ than ozone $(>50 \%$ conversion). Photolysis achieved almost complete removal of both pesticides within $5 \mathrm{~h}$ when using a high pressure mercury lamp, and a conversion of about $40 \%$ with a low power lamp at $254 \mathrm{~nm}$. Preliminary identification of degradation products indicated that hydrochlordecone was formed during photoFenton oxidation of CLD, while for $\beta$-HCH the major product peak exhibited $\mathrm{C}_{3} \mathrm{H}_{3} \mathrm{Cl}_{2}$ as most abundant fragment.

\section{Funding}

Financial support for this work was provided by FSP-Cuba project (Campus France, 29937RD), TATARCOP project (InSTEC, Cuba), and the French Embassy in Cuba, which are gratefully acknowledged.

\section{ORCID}

Carine Julcour (iD) http://orcid.org/0000-0002-9364-4862 Hélène Chaumat iD http://orcid.org/0000-0002-0360-1464

Felipe Ramon-Portugal (iD) http://orcid.org/0000-0002-9519-9707

Ulises J. Jáuregui-Haza (iD http://orcid.org/0000-0002-6943-4873

\section{References}

[1] Cabidoche, Y. M.; Achard, R.; Cattan, P.; Clermont-Dauphin, C.; Massat, F.; Sansoulet, J. Long-term pollution by chlordecone of tropical volcanic soils in the French West Indies: A simple leaching model accounts for current residue. Environ. Pollut. 2009, 157, 1697-1705.

[2] Coat, S.; Monti, D.; Legendre, P.; Bouchon, C.; Massat, F.; Lepoint, G. Organochlorine pollution in Tropical Givers (Guadeloupe): Role of ecological factors in food web bioaccumulation. Environ. Pollut. 2011, 159, 1692-1701.

[3] Stockholm Convention. Listing of POPs in the Stockholm Convention: Annex A. <http://chm.pops.int/Convention/The\%20POPs/ tabid/673/language/fr-CH/Default.aspx $>$ Accessed 26 April 2017. 
[4] Kilzer, L.; Scheunert, I.; Geyer, H.; Klein, W.; Korte, F. Laboratory screening of the volatilization rates of organic chemicals from water and soil. Chemosphere 1979, 8, 751-761.

[5] Dubuisson, C.; Héraud, F.; Leblanc, J. C.; Gallotti, S.; Flamand, C.; Blateau, A.; Volatier, J. L. Impact of subsistence production on the management options to reduce the food exposure of the martinican population to chlordecone. Regul. Toxicol. Pharm. 2007, 49, 5-16.

[6] Cabidoche, Y.-M.; Lesueur-Jannoyer, M. Contamination of harvested organs in root crops grown on chlordecone-polluted soils. Pedosphere 2012, 22, 562-571.

[7] Guldner, L.; Multigner, L.; Héraud, F.; Monfort, C.; Thomé, J. P.; Giusti, A.; Cordier, S. Pesticide exposure of pregnant women in Guadeloupe: Ability of a food frequency questionnaire to estimate blood concentration of chlordecone. Environ. Res. 2010, 110, 146-151.

[8] Landau-Ossondo, M.; Rabia, N.; Jos-Pelage, J.; Marquet, L. M.; Isidore, Y.; Saint-Aimé, C. ARTAC International research group on pesticides. Why pesticides could be a common cause of prostate and breast cancers in the French Caribbean Island, Martinique. An overview on key mechanisms of pesticide-induced cancer. Biomed. Pharmacother. 2009, 63, 383-395.

[9] Environmental Protection Agency. Toxicological review of chlordecone (Kepone). US-EPA Publications EPA/635/R-07/004F. 2009.

[10] Multigner, L.; Ndong, J. R.; Giusti, A.; Romana, M.; Delacroix-Maillard, H.; Cordier, S.; Blanchet, P. Chlordecone exposure and risk of prostate cancer. J. Clin. Oncol. 2010, 28, 3457-3462.

[11] Calvelo. R.; Monterroso, C.; Macias, F.; Camps-Arbestain, M. Distribution pathways of hexachlorocyclohexane isomers in a soil-plantair system. A case study with cynara scolymus L. and Erica sp. plants grown in a contaminated site. Environ. Pollut. 2008, 155, 350-358.

[12] Cabidoche, Y. M.; Lesueur-Jannoyer, M. Pollution durable des sols par la chlordécone aux antilles: Comment la gérer ? Innov. Agron. 2011, 16, 117-133.

[13] Rateau, F. Les produits phytosanitaires dans les cours d'eau de Martinique - 2008-2012. Office De l'Eau Martinique. 2013

[14] Quintero, J. C.; Moreira, M. T.; Feijoo, G.; Lema, J. M. Anaerobic degradation of hexachlorocyclohexane isomers in liquid and soil slurry systems. Chemosphere 2005, 61, 528-536.

[15] Fernández-Bayo, J. D.; Saison, C.; Voltz, M.; Disko, U.; Hofmann, D.; Berns, A.-E. Chlordecone fate and mineralisation in a tropical soil (andosol) microcosm under aerobic conditions. Sci. Total Environ. 2013, 463, 395-403.

[16] Šojić, D.; Despotović, V.; Orčić, D.; Szabó, E.; Arany, E.; Armaković, S.; Sajben-Nagy, E. Degradation of thiamethoxam and metoprolol by $\mathrm{UV}, \mathrm{O}_{3}$ and $\mathrm{UV} / \mathrm{O}_{3}$ hybrid processes: Kinetics, degradation intermediates and toxicity. J. Hydrol. 2012, 472, 314-327.

[17] Nienow, A.-M.; Bezares-Cruz, J.-C.; Poyer, I.-C.; Hua, I.; Jafvert, C.T. Hydrogen peroxide-assisted UV photodegradation of lindane. Chemosphere 2008, 72, 1700-1705.
[18] Senthilnathan, J.; Philip, L. Elimination of pesticides and their formulation products from drinking water using thin film continuous photoreactor under solar radiation. Sol. Energy. 2012, 86, 2735-2745.

[19] Begum, A.; Gautam, S. K. (2012) Endosulfan and lindane degradation using ozonation. Environ. Technol. 2012, 33, 943-949.

[20] Nitoi, I.; Oncescu, T.; Oancea, P. Mechanism and kinetic study for the degradation of lindane by photo-fenton process. J. Ind. Eng. Chem. 2013, 19, 305-309.

[21] Rao, Y. F.; Chu, W. A new approach to quantify the degradation kinetics of linuron with $\mathrm{UV}$, ozonation and $\mathrm{UV} / \mathrm{O}_{3}$ processes. Chemosphere 2009, 74, 1444-1449.

[22] Chelme-Ayala, P.; El-Din, M. G.; Smith, D. W. Degradation of bromoxynil and trifluralin in natural water by direct photolysis and UV plus $\mathrm{H}_{2} \mathrm{O}_{2}$ advanced oxidation process. Water Res. 2010, 44, 22212228.

[23] Chu, W.; Rao, Y.-F. Photocatalytic oxidation of monuron in the suspension of $\mathrm{WO}_{3}$ under the irradiation of UV-visible light. Chemosphere 2012, 86, 1079-1086.

[24] Benitez, F. J.; Acero, J. L.; Real, F. J.; Roman, S. Oxidation of MCPA and 2, 4-D by UV radiation, ozone, and the combinations $\mathrm{UV} / \mathrm{H}_{2} \mathrm{O}_{2}$ and $\mathrm{O}_{3} / \mathrm{H}_{2} \mathrm{O}_{2}$. J. Environ. Sci. Heal. B. 2004, 39(3), 393-409.

[25] Kitchens, J.-A. Dehalogenation of halogenated compounds. US Patent No. 4,144,152, March 3, 1979.

[26] Belghit, H.; Colas, C.; Bristeau, S.; Mouvet, C.; Maunit, B. Liquid chromatography-High-resolution mass spectrometry for identifying aqueous chlordecone hydrate dechlorinated transformation products formed by reaction with zero-valent Iron. Int. J. Environ. An. Ch. 2015, 95, 93-105.

[27] Ormad, M. P.; Miguel, N.; Lanao, M.; Mosteo, R.; Ovelleiro, J. L. Effect of application of ozone and ozone combined with Hydrogen peroxide and titanium dioxide in the removal of pesticides from water. Ozone-Sci. Eng. 2010, 32, 25-32.

[28] Usman, M.; Tascone, O.; Faure, P.; Hanna, K. Chemical oxidation of hexachlorocyclohexanes (HCHs) in contaminated soils. Sci. Total Environ. 2014, 476, 434-439.

[29] Waclawek, S.; Antos, V.; Hrabak, P.; Cernik, M.; Elliott, D. Remediation of hexachlorocyclohexanes by electrochemically activated persulfates. Environ. Sci. Pollut. Res. 2016, 23(1), 765-773.

[30] Chan, K. H.; Chu, W. Modeling the reaction kinetics of fenton's process on the removal of atrazine. Chemosphere 2003, 51, 305-311.

[31] López-López, A.; Pic, J. S.; Debellefontaine, H. Ozonation of azo dye in a semi-batch reactor: A determination of the molecular and radical contributions. Chemosphere 2007, 66, 2120-2126.

[32] Chu, W.; Tsui, S. M. Photo-sensitization of diazo disperse dye in aqueous acetone. Chemosphere 1999, 39, 1667-1677.

[33] Bolton, J. R.; Cater, S. R. Homogeneous photodegradation of pollutants in contaminated water: An introduction, Aquat. Surf. Photochem. 1994, 33, 467-490. 